\title{
Short-Term Influences of Peanut-Biochar Addition on Abandoned Orchard Soil Organic N Mineralization in North China
}

\author{
Jingjing Chang, Xianxiang Luo*, Mingchan Li, Zhenyu Wang, Hao Zheng \\ Key Lab of Marine Environmental Science and Ecology, Ministry of Education, \\ Ocean University of China, Qingdao 266100, P.R. China
}

Received: 11 February 2015

Accepted: 15 October 2015

\begin{abstract}
In recent years, biochar, a new environmentally functional material, has received widespread attention as a soil amendment for its special structures and characteristics, such as improving soil texture and increasing crop yield. However, controversies still exist for the effects of biochar addition to soil nitrogen(N) cycles. This study focuses on the influences of $350^{\circ} \mathrm{C}$ peanut biochar application on $\mathrm{N}$ mineralization in abandoned orchard soil during a 46-day incubation. The treatments contained control (CK), 1\% biochar (BC), and 3\% biochar (BC). Results showed that $350^{\circ} \mathrm{C}$ peanut biochar increased soil $\mathrm{pH}$ and $\mathrm{EC}$, but decreased soil urease activities significantly. Biochar decreased soil net-mineralized $\mathrm{N}$ significantly, and a higher biochar addition content resulted in lower soil mineralized $\mathrm{N}$ concentration. $\mathrm{NO}_{3}^{-}-\mathrm{N}$ content accounted for more than $94 \%$ of soil inorganic $\mathrm{N}$ for all three treatments during the entire incubation time, while the presence of biochar did not change this characteristic. Conclusions indicated that the addition of $350^{\circ} \mathrm{C}$ peanut biochar significantly inhibited orchard soil $\mathrm{N}$ mineralization in a short time by altering soil physical and chemical properties.
\end{abstract}

Keywords: biochar, urease activity, $\mathrm{N}$ mineralization, orchard soil

\section{Introduction}

In recent years biochar has gained popularity in use for soil carbon sequestration and improvement of degraded soils. Biochar is a carbon-rich product from pyrolysis of renewable biomass in a closed system in a low-oxygen or oxygen-free atmosphere [1]. Due to its abundant porous physical structure and large surface area [2], biochar applied to soil may effectively improve soil physical and chemical properties, such as raising acidic soil $\mathrm{pH}$ [3], decreasing soil bulk density [4], and increasing soil field water holding

*e-mail: 1xx81875@ouc.edu.cn capacity [5] and soil cation exchange capacity [6]. The use of $\mathrm{BC}$ as a soil amendment can also bring abundant other advantages, such as suppressing emissions of $\mathrm{CO}_{2}$ and $\mathrm{CH}_{4}$ [7], and reducing $\mathrm{N}_{2} \mathrm{O}$ emissions from soils [8], as well as decreasing nitrate leaching [9]. BC addition has also been reported to increase the concentration of $\mathrm{K}$ [10], $\mathrm{Ca}$, and $\mathrm{Mg}$, and improved crop yields [11]. These effects may be associated with $\mathrm{BC}$-induced enhancement in the activity of beneficial soil microbes [12] and increased soil water retention capacity [13].

Inorganic $\mathrm{N}$ is an important soil nutrient produced by $\mathrm{N}$ mineralization processes which depolymerizes organic $\mathrm{N}$ into inorganic $\mathrm{N}$ [14]. $\mathrm{N}$ mineralization is affected by soil organic matter, total $\mathrm{N}$, temperature and moisture 
[15], bulk density and $\mathrm{pH}$ value [16], salt content [17], and $\mathrm{C} / \mathrm{N}$ ratio [18], etc. Otherwise, urease activity reflects the transformation ability of soil organic $\mathrm{N}$ to inorganic $\mathrm{N}$ and soil inorganic $\mathrm{N}$ supply capacity, and it is a key enzyme for nitrogen transformation [19]. In this paper, as temperature and moisture were set as fixed values that are benifical to $\mathrm{N}$ mineralization, our study mainly focused on soil $\mathrm{pH}$ and EC (closely related to salt content), which can reflect the basic physical and chemical characteristics of soil. At the same time, the effect of soil urease activities on soil $\mathrm{N}$ mineralization was discussed.

The abundant porous physical structure and large surface area [2] of biochar may effectively improve soil physical and chemical properties, thus affecting soil $\mathrm{N}$ mineralization. However, the effects of biochar addition on soil $\mathrm{N}$ cycles - especially the $\mathrm{N}$ mineralization process that reflects the ability of soil $\mathrm{N}$ supply and its possible mechanism - still remains controversial. Previous studies indicated that influences of biochar application on soil $\mathrm{N}$ mineralization were very complicated. Stimulative, inhibitory effects and no effect of biochar addition on soil $\mathrm{N}$ mineralization all occurred. For example, the addition of biochar decreased Gleyic Phaeozem soil N mineralization due to short-term $\mathrm{N}$ immobilization by microorganisms [20]. A similar study [21] also found that biochar's incompletely pyrolytic and labile feedstock $\mathrm{C}$ increased calcareous agricultural soil C:N ratio and finally inhibited soil $\mathrm{N}$ mineralization. Meanwhile, biochar amendment decreased coarse soil microbial activities and decreased soil $\mathrm{N}$ mineralization [22]. But another study suggested that fresh and aged biochar applied to agriculural soil and grassland soil had little influence on the decomposition of nitrogenous organic compounds and soil $\mathrm{N}$ mineralization rate [23]. However, biochar addition can increase forest soil $\mathrm{N}$ mineralization and improve nutrient availability by increasing the quantity and activity of microbes [24] by adsorbing phenolic compounds that exist widely in the forest.

In this study, a 46 day incubation was designed in order to evaluate the influence of peanut biochar (produced under $350^{\circ} \mathrm{C}$ ) application on orchard sandy loam soil net $\mathrm{N}$ mineralization. We hypothesize that the application of alkaline biochar could further raise orchard soil $\mathrm{pH}$ and EC, biochar itself may release some toxic compounds or adsorb some soil organic matter and nutrients in the short term, which reduces microbial activity such as enzyme activities. Therefore, we suppose that the application of peanut biochar on orchard sandy loam soil may change soil physical and chemical properties, thus affecting soil organic $\mathrm{N}$ mineralization. The treatments contain control (CK), $1 \% \mathrm{BC}, 3 \% \mathrm{BC}$. The objectives of this study are:
1. Evaluate orchard sandy loam soil net $\mathrm{N}$ mineralization by different biochar addition rates.

2. Analyze the possible main factors that may affect sandy loam soil $\mathrm{N}$ mineralization by biochar application.

\section{Materials and Methods}

\section{Soil and Biochar}

Surface soil $(0-20 \mathrm{~cm})$ was collected from orchard soil abandoned for two years in Zhaoyuan, Shandong province, China. Soil type was sandy loam. Soil samples were taken back to the laboratory. After natural air drying, the fine roots and rocks were removed and soil was ground to pass through a $2 \mathrm{~mm}$ sieve, then the soil was mixed to ensure homogeneity. Prior to use, these soil samples were moistened to $80 \%$ of the water-holding capacity and preincubated in a constant temperature incubator in order to activate the soil microbes for a week at $30^{\circ} \mathrm{C}$.

Biochar samples were produced from peanut shell through slow pyrolysis at $350^{\circ} \mathrm{C}$ [25]. Biochar samples were also ground to pass through a $2 \mathrm{~mm}$ sieve for further analysis.

\section{Soil and BiocharAnlaysis}

Soil and biochar total carbon (C) and nitrogen (N) were determined through combustion with a FLASH-2000 elemental analyzer (Elementar, USA). $\mathrm{NO}_{3}^{-}-\mathrm{N}$ was determined by phenol disulfonic acid using spectrophotometric methods. $\mathrm{NH}_{4}^{+}-\mathrm{N}$ was measured with indophenol blue reagent [26]. Urease activities were analyzed by Spectrophotometer colorimetric method after incubation at $37^{\circ} \mathrm{C}$ for $24 \mathrm{~h}$ [27]. The moisture content was measured by gravimetry. Soil $\mathrm{pH}$ was measured in 1:2.5 (w/v; $\left.\mathrm{g} \mathrm{cm}^{-3}\right)$ soil-to-deionized water mixtures by a $\mathrm{pH}$-meter (AB15, Fisher Scientific, USA), and $\mathrm{pH}$ of biochar was determined with a 1:20 (w/v) ratio after being shaken for $24 \mathrm{~h}$. Each sample was determined with three duplicates. Soil and biochar characteristics are presented in Table 1. Soil inorganic nitrogen of the study area maintained a very low level, and more than $98 \%$ of soil nitrogen was presented in the form of organic nitrogen.

\section{Laboratory Incubation}

Influences of biochar addition on sandy loam soil organic $\mathrm{N}$ mineralization dynamics were studied by a laboratory incubation experiment for 46 days. Treatments

Table 1. Chemical properties of the soil and biochar used in the experiment.

\begin{tabular}{|c|c|c|c|c|c|c|c|}
\hline & $\mathrm{pH}$ & $\begin{array}{c}\mathrm{TC} \\
(\%)\end{array}$ & $\begin{array}{c}\mathrm{TN} \\
(\%)\end{array}$ & $\begin{array}{c}\mathrm{NH}_{4}{ }^{+}-\mathrm{N} \\
(\mathrm{mg} / \mathrm{kg})\end{array}$ & $\begin{array}{c}\mathrm{NO}_{3}-\mathrm{N} \\
(\mathrm{mg} / \mathrm{kg})\end{array}$ & $\begin{array}{c}\text { Organic-N } \\
(\mathrm{g} / \mathrm{kg})\end{array}$ & Ash $(\%)$ \\
\hline Soil & 7.40 & $1.22 \pm 0.16$ & $0.15 \pm 0.004$ & $2.08 \pm 0.04$ & $15.74 \pm 0.28$ & 1.48 & \\
\hline Biochar & 8.59 & $44.02 \pm 0.48$ & $1.01 \pm 0.006$ & $3.17 \pm 0.14$ & $0.94 \pm 0.17$ & - & 27.9 \\
\hline
\end{tabular}


contain: control (CK), 1\% biochar (BC), and 3\% biochar (BC). $40 \mathrm{~g}$ of biochar-amended soils were packed into 105 polypropylene cups (height* lower caliber* upper caliber, $47 \mathrm{~mm} * 57 \mathrm{~mm} * 74 \mathrm{~mm}$ ), and several little holes were made in the lips to allow gas exchange, but as much as possible to minimize water loss. Soil moisture was adjusted to $80 \%$ field capacity and it was maintained by weighing the cups every three days (and using wet distilled water if needed). Related parameters were measured after $1,6,11,18,25,34$, and 46 days. Each treatment was set up in triplicate.

\section{Calculations}

The net $\mathrm{N}$ mineralized was reported directly as $\mathrm{mg}$ $\mathrm{N} \mathrm{kg}^{-1}$ soil. Net amount of soil $\mathrm{N}$ mineralization was calculated as the difference between the total inorganic $\mathrm{N}$ content determined between mineralized $\mathrm{N}$ after the incubation time and initial time. Net $\mathrm{N}$ mineralization rate was calculated as the difference between the net mineralized $\mathrm{N}$ divided by incubation time [28].

\section{Statistical Analysis}

All results in this article were gained from experiments. The graph was drawn from origin 8.6, and statistical analysis of data using SPSS20.0.ANOVA was used to test all experimental data by Duncan's test. All analyses were considered significant when $\mathrm{P}<0.05$. Correlation analysis was used to evaluate the correlation between different parameters.

\section{Results and Discussion}

\section{Net N Mineralization Dynamics}

Mineralization is the process of decomposition of organic matter, mediated by soil microbes. Results of a short-term incubation experiment showed that peanut biochar significantly decreased sandy loam soil mineralized $\mathrm{N}$ content, and a higher biochar addition resulted in lower net amount of $\mathrm{N}$ mineralization (Fig. 1). Net $\mathrm{N}$ mineralization rate increased quickly in the first 11 days and reached a maximum, with rate values of three treatments, respectively, at $2.69(\mathrm{CK}), 2.78(1 \% \mathrm{BC}), 2.08$ $(3 \% \mathrm{BC}) \mathrm{mg} / \mathrm{kg} / \mathrm{d}$ on day 11 . After $11 \mathrm{~d}, \mathrm{~N}$ mineralization rates began to slow down, and rates were 2.69 (CK), $2.78(1 \% \mathrm{BC})$, and $2.08(3 \% \mathrm{BC}) \mathrm{mg} / \mathrm{kg} / \mathrm{d}$ at the last day, respectively. The net amount of $\mathrm{N}$ mineralization always kept an increase trend and reached 49.24 (CK), 47.07 (1\%BC), and $43.07(3 \% \mathrm{BC}) \mathrm{mg} / \mathrm{kg}$ at $46 \mathrm{~d}$.

Our results were consistent with most previous studies for agricultural soils by biochar application [20$22,29]$, but some of them considered that the resulting $\mathrm{N}$ immobilization phenomenon was just transient and may only last a few months in the soil. Since soil water content was controlled through weighing the cups every three days, denitrification was not a key factor for $\mathrm{N}$

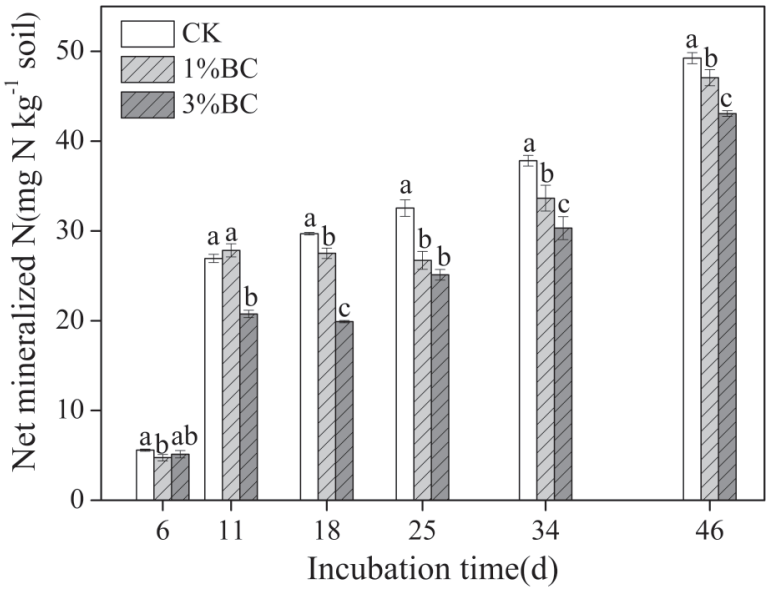

Fig. 1. Effects of biochar application on soil net mineralized N. CK: no biochar addition; $1 \%$ BC: biochar was added at a rate of $1 \%(\mathrm{w} / \mathrm{w}) ; 3 \% \mathrm{BC}$ : biochar was added at a rate of $3 \%$ $(w / w)$. Different letters mean a significant difference among the treatments, which was analyzed by the Duncan test $(\mathrm{P}<0.05)$ using SPSS 20.0. Error bars mean standard error $(n=3)$.

losses [30]. One of the possible reasons for decreased $\mathrm{N}$ mineralization was that although most of $\mathrm{C}$ in biochars were stable in aromatic forms and unavailable easily to microbes, it can provide a little source of metabolizable $\mathrm{C}$ $[31,32]$. For this study, peanut biochar was produced under $350^{\circ} \mathrm{C}$. This is particularly true for biochar created under low pyrolysis temperatures containing less aromaticity but higher aliphatic $\mathrm{C}$ content than biochars produced at high temperatures [33]. A higher $\mathrm{C}: \mathrm{N}$ ratio of carbon-rich biochar might promote $\mathrm{N}$ immobilization in a short time. Furthermore, biochar addition may change original soil physical and chemical properties, or alter soil microbial community structure or composition [34], thus affecting soil $\mathrm{N}$ mineralization.

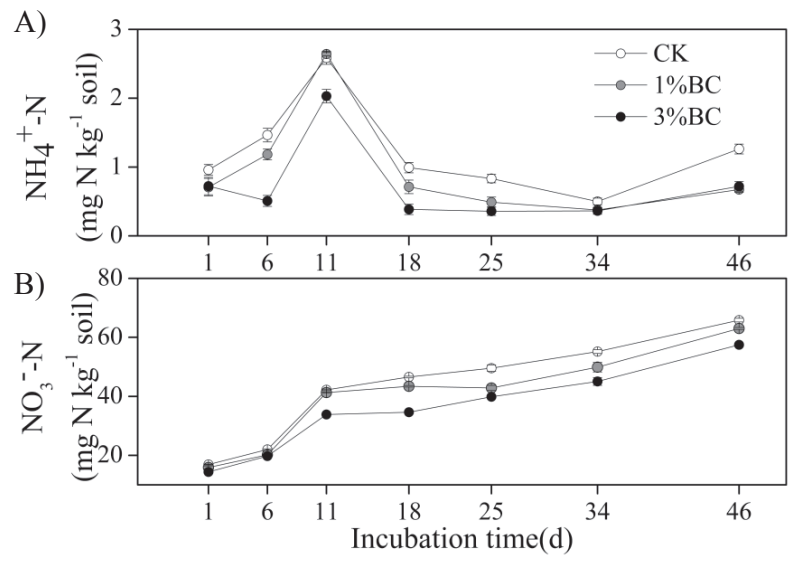

Fig. 2. Effects of biochar application on dynamic changes in soil $\mathrm{NH}_{4}^{+}-\mathrm{N}$ (Fig. 2A) and $\mathrm{NO}_{3}^{-}-\mathrm{N}$ (Fig. 2B). CK: no biochar addition; $1 \% \mathrm{BC}$ : biochar was added at a rate of $1 \%(\mathrm{w} / \mathrm{w}) ; 3 \%$ BC: biochar was added at a rate of $3 \%(w / w)$. Different letters mean a significant difference among the treatments, which was determined by the Duncan test $(\mathrm{P}<0.05)$ using SPSS 20.0. Error bars mean, standard error $(n=3)$. 


\section{Dynamic Changes of Soil $\mathrm{NH}_{4}^{+}-\mathrm{N}^{-}$and $\mathrm{NO}_{3}{ }^{-} \mathrm{N}$}

In order to clearly study biochar addition effects on sandy loam soil $\mathrm{N}$ mineralization, soil $\mathrm{NH}_{4}^{+}{ }^{+} \mathrm{N}$ and $\mathrm{NO}_{3}^{-}-\mathrm{N}$ were analyzed. $\mathrm{NH}_{4}^{+}-\mathrm{N}$ and $\mathrm{NO}_{3}^{-}-\mathrm{N}$ contents at all treatments increased quickly in the first 11 days; however, $\mathrm{NH}_{4}^{+}-\mathrm{N}$ began to decrease fast between 11-18 days and after $18 \mathrm{~d}$, change of $\mathrm{NH}_{4}{ }^{+} \mathrm{N}$ content was little (value $<1 \mathrm{mg} / \mathrm{kg}$ ) (Fig. 2A). At whole incubation stage, two biochar application treatments decreased sandy loam soil $\mathrm{NH}_{4}{ }^{+} \mathrm{N}$ content significantly $(\mathrm{P}<0.05)$. This may be related to adsorption of $\mathrm{NH}_{4}^{+}-\mathrm{N}$ by biochar [35]. On the whole, there was no significant difference between $\mathrm{NH}_{4}^{+}-\mathrm{N}$ content for the two biochar treatments.

However, $\mathrm{NO}_{3}^{-}-\mathrm{N}$ kept a slow increase trend after $11 \mathrm{~d}$, and $\mathrm{NO}_{3}^{-}-\mathrm{N}$ content reached $65.82(\mathrm{CK}), 63.00$ $(1 \% \mathrm{BC})$, and $57.45(3 \% \mathrm{BC}) \mathrm{mg} / \mathrm{kg}$ at $46 \mathrm{~d}$ (Fig. $2 \mathrm{~B})$. At the whole incubation time, $\mathrm{NO}_{3}^{-}-\mathrm{N}$ content accounted for more than $94 \%$ of soil inorganic $\mathrm{N}$ for all treatments, while $\mathrm{NH}_{4}^{+}-\mathrm{N}$ proportion was lower than $6 \%$. This indicated that nitrification occurred quickly after organic $\mathrm{N}$ converted to $\mathrm{NH}_{4}^{+}-\mathrm{N}$. The concentration of $\mathrm{NO}_{3}^{-}-\mathrm{N}$ was significantly positively correlated with soil net amount of $\mathrm{N}$ mineralization $(\mathrm{R}=0.996, \mathrm{P}<0.001, \mathrm{n}=18)$. Treatment of $3 \% \mathrm{BC}$ significantly decreased soil nitrification rate. For the first 11 days average nitrification rates of three treatments reached $2.53(\mathrm{CK}), 2.49(1 \% \mathrm{BC})$, and 1.69 $(3 \% \mathrm{BC}) \mathrm{mg} / \mathrm{kg} / \mathrm{d}$. Two biochar treatments significantly decreased soil $\mathrm{NO}_{3}^{-}-\mathrm{N}$ concentration for whole incubation stage, and a higher biochar addition finally resulted in a lower concentration of $\mathrm{NO}_{3}^{-}-\mathrm{N}(\mathrm{P}<0.05)$.

\section{pH and EC Dynamic Changes}

Soil organic $\mathrm{N}$ mineralization is a biochemical process dominated by the microorganism. Soil basic physical and chemical properties such as $\mathrm{pH}$ and EC may impact

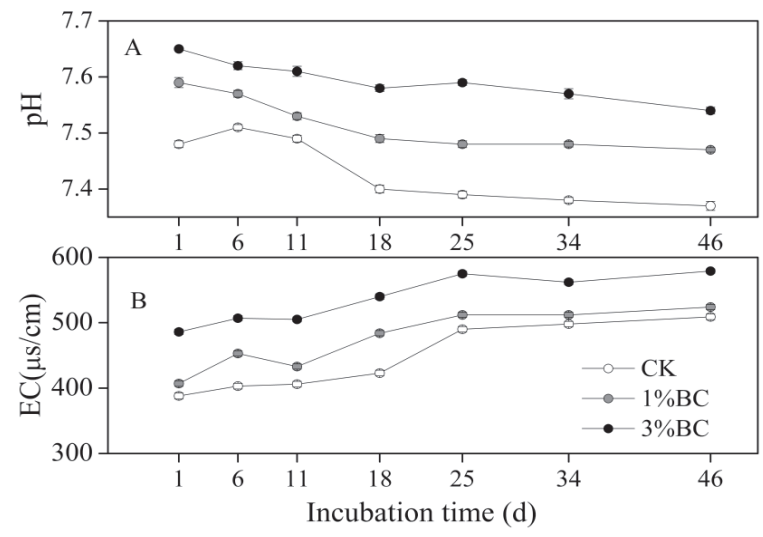

Fig. 3. Effects of biochar application for dynamic changes of soil $\mathrm{pH}$ and electrical conductivity. CK: no biochar addition; $1 \%$ $\mathrm{BC}$ : biochar was added at a rate of $1 \%(\mathrm{w} / \mathrm{w}) ; 3 \% \mathrm{BC}$ : biochar was added at a rate of $3 \%(\mathrm{w} / \mathrm{w})$. Different letters mean values that are significantly different $(\mathrm{p}<0.05)$ as analyzed by factorial ANOVA in SPSS 20.0. Error bars represent standard error $(\mathrm{n}=$ $3)$. microbial mass, activities, and community composition [36]. Compared to control, biochar greatly increased soil $\mathrm{pH}$ and $\mathrm{EC}$, and a higher biochar addition finally resulted in a higher value of soil $\mathrm{pH}$ and EC (Fig. 3). Our result was in accordance with earlier studies that soil $\mathrm{pH}$ was increased with biochar addition [25], which concluded that $\mathrm{pH}$ values and ash contents were positively correlated, and the increased soil $\mathrm{pH}$ may be due to the intrinsic minerals in biochar. Previous studies also showed biochar contained some elements such as $\mathrm{K}, \mathrm{Ca}$, and $\mathrm{Mg}[10,11]$, and when it was applied with soil, biochar could increase soil-soluble $\mathrm{K}^{+}, \mathrm{Ca}^{2+}$, and $\mathrm{Mg}^{2+}$, and this may be one of the reasons biochar increased soil EC.

Two biochar treatments increased soil $\mathrm{pH}$ significantly in all incubation time, and average value of soil $\mathrm{pH}$ was $0.08 \pm 0.03(1 \% \mathrm{BC})$ and $1.62 \pm 0.04(3 \% \mathrm{BC})$ unit higher than control; and average value of EC was $30 \mu \mathrm{s} /$ $\mathrm{cm}$ and $91 \mu \mathrm{s} / \mathrm{cm}$ higher than control. Changes in soil $\mathrm{pH}$ and EC may affect soil enzyme activities (Fig. 4). EC was significantly negatively correlated with urease activities $(\mathrm{R}=0.802, \mathrm{P}<0.001, \mathrm{n}=18)$. Decreased soil urease activities may finally inhibit soil $\mathrm{N}$ mineralization. Soil $\mathrm{pH}$ was significantly negatively correlated with soil net amount of $\mathrm{N}$ mineralization and $\mathrm{NO}_{3}^{-}-\mathrm{N}$ content $\left(\mathrm{R}_{\text {net mineralized N }}=-0.591, \mathrm{P}<0.01, \mathrm{n}=18 ; \mathrm{R}_{\mathrm{NO}_{3}-\mathrm{N}}=-0.640\right.$, $\mathrm{P}<0.01, \mathrm{n}=18$ ).

All treatmens of soil $\mathrm{pH}$ showed a decreasing trend while EC showed an increasing trend along with the extension of incubation time. This phenomenon may be due to the increaseing trend of soil $\mathrm{NO}_{3}^{-}-\mathrm{N}$ content along the whole incubation time.

\section{Dynamic Changes of Soil Urease Activities}

Soil enzyme catalysis conducted soil biological processes such as soil N mineralizaiton. Enzyme activities are regarded as key quality indicators that could respond

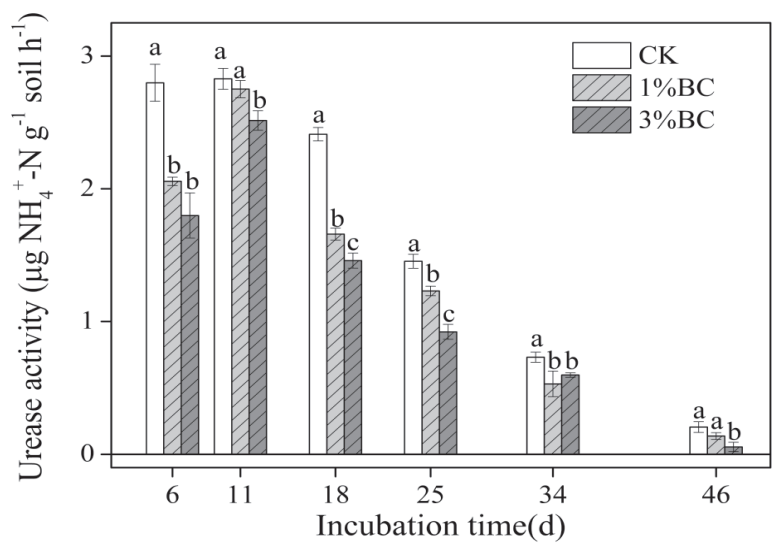

Fig. 4. Effects of biochar application on dynamic changes of soil urease activities. CK: no biochar addition; 1\% BC: biochar was added at a rate of $1 \%(\mathrm{w} / \mathrm{w}) ; 3 \% \mathrm{BC}$ : biochar was added at a rate of $3 \%(\mathrm{w} / \mathrm{w})$. Different letters mean values that are significantly different $(\mathrm{p}<0.05)$ as analyzed by factorial ANOVA in SPSS 20.0. Error bars represent standard error $(n=3)$. 
to alterations in soil management in a shorter period of time [37]. Since soil urease is an important enzyme involved in the $\mathrm{N}$ transformation process and it can hydrolyze urea [19], this research focus on the effects of biochar addition on soil urease activities. Compared to control, two biochar treatments significantly decreased soil urease activities $(\mathrm{p}<0.05)$, and higher biochar addition resulted in lower urease activities (Fig. 4). Our results were in accordance with earlier studies that biochar reduced soil urease activities, and urease activities decreased with the increasing rate of biochar additions [27]. Possible reasons may be the following: biochar itself may release some volatile toxic compounds that inhibit soil microbial activities, such as PAHs [38], ethylene [39], or PHCs [40]; and the release of toxic components along with biochar's aging in soils suggests that biochar may inhibit soil microbial activities, thus decreasing $\mathrm{N}$ mineralization. Moreover, the enriched pore structure of biochar may adsorb soil enzymes [41], and then inhibit soil $\mathrm{N}$ mineralization.

Soil urease activities showed a decreasing trend with the extension of incubation time. At 46d, values of urease activities of all three treatments were lower than $0.2(\mu \mathrm{g}$ $\mathrm{NH}_{4}^{+}-\mathrm{N} \mathrm{g}^{-1}$ soil $^{-1}$ ). Soil urease activity was significantly positively correlated with soil net $\mathrm{N}$ mineralization rate $(\mathrm{R}=0.698, \mathrm{P}<0.001, \mathrm{n}=18)$.

\section{Conclusions}

This research showed that peanut biochar produced under low temperature significantly inhibit sandy loam soil $\mathrm{N}$ mineralization. Higher biochar addition finally resulted in a lower concentration of soil net mineralized $\mathrm{N}$. Biochar inhibits soil $\mathrm{N}$ mineralization by changing soil physicochemical properties, such as soil $\mathrm{pH}, \mathrm{EC}$, and urease activitues. This suggested that biochar has certain effects of protecting fertilizer and $\mathrm{N}$ immobilization limiting the $\mathrm{N}$ losses in the external environment. For the whole incubation time, $\mathrm{NO}_{3}^{-}-\mathrm{N}$ content dominated for more than $94 \%$ of soil mineralized $\mathrm{N}$ for all three treatments. Considering that biochar had little adsorption of nitrate, further study needs to be aware of nitrate pollution of groundwater. Furthermore, feedstock types, pyrolysis conditions, $\mathrm{pH}, \mathrm{N}$, and $\mathrm{C}$ content of biochar as well as soil types varied greatly among different experiments, which may lead to different results of biochar's role on $\mathrm{N}$ mineralization. Therefore, specific mechanisms are needed to be further discussed by biochar addition in sandy loam soil $\mathrm{N}$ mineralization.

\section{Acknowledgements}

This study was funded by the NSFC Fund (Grant No. 41573089), the National Marine Public Welfare Research Project of China (Grant No. 201305021) and the National Marine Public Welfare Research Project of China (Grant No. 201405007).

\section{References}

1. LEHMANN J., JOSEPH S. Biochar for environmental management: An introduction. In Biochar for Environmental Management, Science and Technology; Lehmann J., Joseph S., Eds.; Earthscan: London, UK, 1, 2009.

2. BROWN R.A., KERCHER A. K., NGUYEN T. H., NAGLE D.C., BALL W.P. Production and characterization of synthetic wood chars for use as surrogates for natural sorbents. Org. Geochem. 37, 321, 2006.

3. XU H.J., WANG X.H., LI H., YAO H.Y., SU J.Q., ZHU Y.G. Biochar impacts soil microbial community composition and nitrogen cycling in an acidic soil planted with rape. Environ. Sci. Technol. 48 (16), 9391, 2014.

4. PROMMER J., WANEK W., HOFHANSL F., TROJAN D., OFFRE P., URICH T., SCHLEPER C., SASSMANN S., KITZLER B., SOJA G., HOOD-NOWOTNY R.C. Biochar Decelerates Soil Organic Nitrogen Cycling but Stimulates Soil Nitrification in a Temperate Arable Field Trial. PloS One. 9 (1), e86388, 2014.

5. JEFFERY S., VERHEIJEN F. G.A., VAN DER VELDE M., BASTOS A.C. A quantitative review of the effects of biochar application to soils on crop productivity using meta-analysis. Agr. Ecosyst. Environ.144 (1), 175, 2011.

6. LIANG B., LEHMANN J., SOLOMON D., KINYANGI J., GROSSMAN J., O'NEILL B., SKJEMSTAD J. O., THIES J., LUIZ F.J. Black carbon increases cation exchange capacity in soils. Soil Sci. Soc. Am. J. 70 (5), 1719, 2006.

7. SPOKAS K., REICOSKY D.C. Impacts of sixteen different biochars on soil greenhouse gas production. Ann. Environ. Sci. 3, 179, 2009.

8. KAMMANN C.I., RATERING S., ECKHARD C., MÜLLER C. Biochar and hydrochar effects on greenhouse gas (carbon dioxide, nitrous oxide, and methane) fluxes from soils. J. Environ. Qual. 41, 1052, 2012.

9. SINGH B.P., HATTON B.J., SINGH B., COWIE A.L., KATHURIA A. Influence of biochars on nitrous oxide emission and nitrogen leaching from two contrasting soils. J. Environ. Qual. 39, 1224, 2010.

10. VAN ZWIETEN L., KIMBER S., MORRIS S., CHAN K. Y., DOWNIE A., RUST J., JOSEPH S., COWIE A. Effects of biochar from slow pyrolysis of papermill waste on agronomic performance and soil fertility. Plant Soil. 327 (1-2), 235-246, 2010.

11. MAJOR J., RONDON M., MOLINA D., RIHA S., LEHMANN J. Maize yield and nutrition during 4 years after biochar applicationto a Colombian savanna Oxisol. Plant Soil. 333,117, 2010.

12. LEHMANN, J., RILLIG M. C., THIES J., MASIELLO C. A., HOCKADAY W. C., CROWLEY D. Biochar effects on soil biota - a review. Soil Biol. Biochem. 43 (9), 1812, 2011.

13. ABEL S., PETERS A., TRINKS S., SCHONSKY H., FACKLAM M., WESSOLEK G. Impact of biochar and hydrochar addition on water retention and water repellency of sandy soil. Geoderman. 202, 183, 2013.

14. HU R., WANG X. P., PAN Y. X., ZHANG Y. F., ZHANG H. Temperature and moisture are the two major environmental factors controlling the activity of microorganisms in soil. Eur. J. Soil. Biol. 62, 66, 2014.

15. XIANG S.R., DOYLE A., HOLDEN P.A., SCHIMEL J.P. Drying and rewetting effects on $\mathrm{C}$ and $\mathrm{N}$ mineralization and microbial activity in surface and subsurface California grassland soils. Soil Biol. Biochem. 40 (9), 2281, 2008.

16. YANG X.Q., HAN Y.Z., LI B., YAN H.B., YANG W.D. Spatiotemporal heterogeneity of soil nitrogen mineralization 
in a Picea stand and its relation to soil physicochemical factors[J]. Acta Ecol. Sin. 35 (2), 20, 2015.

17. CHENG Y., WANG J., MARY B., ZHANG J.B., CAI Z.C., CHANG S.X. Soil pH has contrasting effects on gross and net nitrogen mineralizations in adjacent forest and grassland soils in central Alberta, Canada[J]. Soil Biol. Biochem. 57, 848, 2013.

18. LENTZ R. D., IPPOLITO J.A., SPOKAS K.A. Biochar and Manure Effects on Net Nitrogen Mineralization and Greenhouse Gas Emissions from Calcareous Soil under Corn[J]. Soil Sci. Soc. Am. J. 78 (5), 1641, 2014.

19. MAKOI J.H., NDAKIDEMI P.A. Selected soil enzymes: examples of their potential roles in the ecosystem. Afr. J. Biotechnol. 7 (3), 2008.

20. TAMMEORG P., BRANDSTAKA T., SIMOJOKI A., HELENIUS J. Nitrogen mineralization dynamics of meat bone meal and cattle manure as affected by the application of softwood chip biochar in soil. Earth. Env. Sci. T. R. So. 103 (01), 19, 2012.

21. LENTZ R. D., IPPOLITO J. A., SPOKAS K.A. Biochar and manure effects on net nitrogen mineralization and greenhouse gas emissions from calcareous soil under corn. Soil Sci. Soc. Am. J. 78 (5), 1641, 2014.

22. DEMPSTER D.N., GLEESON D.B., SOLAIMAN Z.M., JONES D.L., MURPHY D. V. Decreased soil microbial biomass and nitrogen mineralization with Eucalyptus biochar addition to a coarse textured soil. Plant Soil. 354 (12), 311, 2012a.

23. DEMPSTER D.N., JONES D.L., MURPHY D.V. Organic nitrogen mineralization in two contrasting agro-ecosystems is unchanged by biochar addition. Soil Biol. Biochem. 48, 47-50, 2012b.

24. KOLB S.E., FERMANICH K. J., DORNBUSH M.E. Effect of charcoal quantity on microbial biomass and activity in temperate soils [J]. Soil Sc. Soc.Am. J. 73 (4), 1173, 2009.

25. ZHENG H., WANG Z.Y., DENG X., ZHAO J., LUO Y., NOVAK J., HERBERT S., XING B.S. Characteristics and nutrient values of biochars produced from giant reed at different temperatures. Bioresource. Technol. 130, 463-471, 2013.

26. LU R.. Analysis Methods of Agrochemistry for Soils, Chinese Agricultural Science and Technology Press, Beijing, 107, 2000 (In Chinese).

27. WU F., JIA Z., WANG S., CHANG S.X., STARTSEV A. Contrasting effects of wheat straw and its biochar on greenhouse gas emissions and enzyme activities in a Chernozemic soil. Biol. Fert. Soils. 49 (5), 555, 2013.

28. ROBERTSON G.P., VITOUSEK P.M. Nitrification potentials in primary and secondary succession. Ecology. 376, 1981.
29. BRUUN E.W., AMBUS P., EGSGAARD H., HAUGGAARD-NIELSEN $\mathrm{H}$. Effects of slow and fast pyrolysis biochar on soil $\mathrm{C}$ and $\mathrm{N}$ turnover dynamics. Soil Biol. Biochem. 46, 73, 2012.

30. JONES D.L., ROUSK J., EDWARDS-JONES G., DELUCA T.H., MURPHY D.V. Biochar-mediated changes in soil quality and plant growth in a three year field trial. Soil Biol. Biochem. 45,113, 2012.

31. CHENG C.H., LEHMANN J., THIES J.E., BURTON S.D. Stability of black carbon in soils across a climatic gradient. J. Geophys. Res.: Biogeosciences (2005-2012), 113 (G2), 2008.

32. SMITH J.L., COLLINS H.P., BAILEY V.L. The effect of young biochar on soil respiration. Soil Biol. Biochem. 42 (12), 2345, 2010.

33. BRUUN S., JENSEN E.S., JENSEN L.S. Microbial mineralization and assimilation of black carbon: Dependency on degree of thermal alteration. Org. Geochem. 39, 839, 2008.

34. STEINBEISS S., GLEIXNER G., ANTONIETTI M. Effect of biochar amendment on soil carbon balance and soil microbial activity. Soil Biol. Biochem. 41, 1301, 2009.

35. YAO Y., GAO B., ZHANG M., INYANG M., ZIMMERMAN.A.R. Effect of biochar amendment on sorption and leaching of nitrate, ammonium, and phosphate in a sandy soil. Chemosphere. 89 (11), 1467, 2012.

36. BÅATH E., ANDERSON T.H. Comparison of soil fungal/ bacterial ratios in a $\mathrm{pH}$ gradient using physiological and PLFA-based techniques. Soil Biol. Biochem. 35, 955, 2003.

37. PAZ-FERREIRO J., GASCÓ G., GUTIÉRREZ B., MÉNDEZ A. Soil biochemical activities and the geometric mean of enzyme activities after application of sewage sludge and sewage sludge biochar to soil. Biol. Fertil. Soils 48, 511, 2011.

38. HALE S.E., LEHMANN J., RUTHERFORD D., ZIMMERMAN A.R., BACHMANN R.T., SHITUMBANUMA V., O'TOOLE A., SUNDQVIST K.L., ARP H.P., CORNELISSEN G. Quantifying the total and bioavailable polycyclic aromatic hydrocarbons and dioxins in biochars. Environ. Sci. Technol. 46 (5), 2830, 2012.

39. SPOKAS K.A., BAKER J.M., REICOSKY D.C. Ethylene: potential key for biochar amendment impacts. Plant Soil. 333, 443, 2010.

40. WANG Z.Y., ZHENG H., LUO Y., DENG X., HERBERT S., XING B.S. Characterization and influence of biochars on nitrous oxide emission from agricultural soil. Environ. Pollut. 174, 289, 2013.

41. PAZ-FERREIRO J., FU S., MÉNDEZ A., GASCÓ G. Biochar modifies the thermodynamic parameters of soil enzyme activity in a tropical soil. J. Soil. Sediment. 15 (3), 578, 2015. 